\title{
CO JEST DOBREM W KODEKSACH ETYCZNYCH FIRM?
}

Przedmiotem naszego zainteresowania są kodeksy etyczne firm, które traktowane są przez kierownictwa firm jako przejaw szlachetności, symbol etycznego działania, jako jeden ze sposobów rozwiązania deficytów etycznych w działalności gospodarczej. Chcieliśmy sprawdzić, czy tak jest rzeczywiście, czy kodeksy etyczne firm mogą pełnić taką rolę. W tym celu postanowiliśmy zbadać, jakie $\mathrm{w}$ kodeksach etycznych są wyobrażenia dobra, czyli tego, co pożądane dla firmy i interesariuszy. Trudno w tym miejscu zaprezentować wszystkie najważniejsze preferencje aksjologiczne obecne $\mathrm{w}$ kodeksach, dlatego przedstawimy tylko te, które dotyczą sposobów tworzenia kodeksów, pojmowania ich roli oraz stosunku do najważniejszych interesariuszy. W ten sposób wyjaśnimy, jak ujmują dobro (to, co pożądane, godne realizacji) twórcy tych dokumentów. Zestawienie oczekiwań etyków wobec kodeksów etycznych firm (ich uzasadnienia, procesu tworzenia, funkcji, wyznaczania powinności wobec interesariuszy) z treścią kodeksów obecnych $\mathrm{w}$ różnych firmach pozwoli ustalić, $\mathrm{w}$ jakim stopniu preferencje twórców kodeksów są zbieżne z wymogami etycznymi. Nasze poszukiwania opierają się na badaniach empirycznych (analizie treści kodeksów za pomocą zestandaryzowanego kwestionariusza; analizę przeprowadzono w pierwszej połowie 2013 r.) i porównaniu wymogów etycznych z deklaracjami i postulatami zawartymi w kodeksach ${ }^{1}$.

${ }^{1}$ Artykuł, w części empirycznej, wykorzystuje niektóre wątki książki T. Czakona: Między paternalizmem a restrykcyjnością. Prawa pracownicze w kodeksach etycznych firm. Torun 2013. 


\section{Oczekiwania etyków wobec kodeksów etycznych firm}

Kodeksy etyczne firm są zjawiskiem coraz bardziej powszechnym. Posiadają je liczne firmy, szczególnie te duże, o zasięgu międzynarodowym, ale znajdziemy je także $w$ wielu mniejszych i małych firmach o zasięgu krajowym czy nawet lokalnym². Kodeksy etyczne często są jednym z elementów polityki firm realizujących programy etyczne, społeczną odpowiedzialność biznesu bądź innych tego typu działań. Wśród badaczy tego zjawiska toczą się dyskusje o wiele spraw, między innymi dotyczą one zasadności używania terminu "kodeksy etyczne”, celowości formułowania kodeksów, ich roli, struktury, właściwych sposobów ich tworzenia i przyjęcia. Dokumenty, które były przedmiotem analizy, nazywane są różnie: kodeksami etycznymi, kodeksami etyki, zasadami postępowania, lecz także kodeksem etyki $i$ postępowania $w$ biznesie, standardami etycznego postępowania, normami i zasadami postępowania określonej firmy lub przedsiębiorstwa. Jednocześnie ukształtował się już zwyczaj nazywania ich kodeksami etycznymi i nie ma sensu z nim walczyć, dlatego w dalszej części (mając świadomość związanych $\mathrm{z}$ tym wątpliwości i nieoczywistości) będziemy się posługiwać tym terminem.

Kodeksy etyczne firm są zbiorem opisów sytuacji, sposobów postępowania, nakazów, zakazów określających pożądane zachowania w firmie oraz zachowania firmy wobec otoczenia. $Z$ tych opisów, nakazów i zakazów łatwiej lub trudniej można wydobyć pewne typy wartości obecne w kodeksie. Kodeksy etyczne firm stanowią - jak pisze Bożena Klimczak - „mieszankę zasad technicznych, rozsądkowych, a także reguł moralnych"3. Cytowana autorka twierdzi, że zazwyczaj posiadają one kilka części, w których deklaruje się określone zachowania wobec interesariuszy: właścicieli, współpracowników, dostawców i nabywców, konkurentów, sąsiadów i społeczeństwa, państwa. Stwierdza również, że kodeksy firm „służą przede wszystkim do informowania «stejkholderów» ${ }^{4}$ o zakresie przyjętych przez firmy zobowiązań społecznych" 5 . W opinii Mirosławy Rybak, kodeksy etyczne firm "określają zakres odpowiedzialności zarządu oraz rady nadzorczej, wynikający z przyjętych przez przedsiębiorstwo zobowiązań wobec społeczeństwa. Zobowiązania te polegają zazwyczaj na promocji dobra,

2 B. Klimczak, Etyka gospodarcza, Wrocław 1999, s. 72.

${ }^{3}$ Ibidem.

${ }^{4}$ Coraz bardziej upowszechnia się tłumaczenie terminu stakeholder na „interesariusz”, co najczęściej oznacza podmioty zainteresowane działaniem firmy, podmioty, na które wpływa firma i one na nią wpływają; przyjmuje się istnienie różnych interesariuszy, o czym dalej.

${ }^{5}$ B. Klimczak, op. cit., s. 73. 
praw ludzkich, korzyści i dobrobytu społecznego, a zakazywaniu działań i zachowań uważanych za zagrażające wymienionym wartościom"6.

Zwolennicy tworzenia kodeksów etycznych firm przytaczają różne argumenty o charakterze mniej lub bardziej fundamentalnym (odwołując się do podmiotowości ludzi) bądź instrumentalnym, traktując kodeksy etyczne jako jedno z narzędzi zarządzania ludźmi bądź tworzenia lepszego wizerunku firmy, mając nadzieję, że "etyka się opłaca"7. Niezależnie od tych szczegółowych motywacji, kodeksy etyczne firm tworzą pewne standardy właściwych, pożądanych (ze względu na stawiane sobie cele) zachowań.

Zgodnie z pewnymi ukształtowanymi wyobrażeniami, kodeksy etyczne firm powinny odnosić się do kilku grup, kilku rodzajów interesariuszy, to znaczy podmiotów (osób, instytucji), które wpływają na działalność firmy i dlatego ich interesy powinny być uwzględniane. Podawane są różne powody obecności i narastającej popularności kodeksów etycznych. B. Klimczak podaje, że świadczą one o prakseologicznym podejściu do moralności kodeksy uznawane są za narzędzie umożliwiające skuteczne działanie.

Ryszard Wiśniewski daje mniej jednoznaczną odpowiedź na pytanie o zasadność tworzenia kodeksów etycznych firm ${ }^{8}$. Uważa on, że tworzenie kodeksów etycznych firm, jako próba instytucjonalizacji moralności, budzi wątpliwość. Jego zdaniem, za obecnością kodeksów etycznych przemawiają: dawność podobnych zjawisk, nowoczesna racjonalizacja moralności, jednoczenie ludzi ponad podziałami, obrona przed chaosem moralnym, konieczność kontroli zachowań9.

Przeciwko obecności kodeksów firm - jak podkreśla Ryszard Wiśniewski - przemawia groźba totalizacji oraz kwestionowanie "doświadczenia godności ludzkiej"10. O ile w dużych, nowoczesnych, demokratycznych społeczeństwach istnieją zjawiska pluralizacji orientacji moralnych, o tyle w małych możliwe są praktyki totalnego nacisku moralnego. Dzieje się to poprzez wykorzystywanie marketingu, reklamy, mediów, sondaży - działań „kompletnie pozbawiających ludzi zdolności samodzielnego wartościowania"11.

Pomimo zgłoszonych wątpliwości, Ryszard Wiśniewski stwierdza, że etyka kodeksowa w biznesie jest potrzebna, pod warunkiem że unika kazuistyki, upodabniania się do regulaminów pracy czy ślubowań.

\footnotetext{
${ }^{6}$ M. Rybak, Etyka menedżera - społeczna odpowiedzialność przedsiębiorstwa, Warszawa 2004, s. 139.

${ }^{7}$ Cz. Porębski, Czy etyka się optaca? Zagadnienia etyki biznesu, Kraków 1997.

8 R. Wiśniewski, Za i przeciw kodyfikacjom etycznym firm, „Diametrios” 2006, nr 6, s. 135-139.

9 Ibidem, s. 136.

${ }^{10}$ Ibidem.

${ }^{11}$ Ibidem.
} 
Badacze kodeksów etycznych firm stwierdzają jednocześnie, że ewentualne korzyści z ich stosowania „zależą od tego, czy kodeksy są szeroko stosowane i akceptowane społecznie. Kodeksy powinny zatem powstawać w wyniku publicznej dyskusji, być przedmiotem nauczania i stać się częścią tradycji przekazywanej $\mathrm{z}$ pokolenia na pokolenie"12. Podobnie sprawę przedstawia Ryszard Banajski ${ }^{13}$, stwierdzając, że praktyczne funkcje kodeksu zależą między innymi od „stopnia aprobaty środowiskowej oraz instytucjonalnej «obudowy» (komisja etyczna, sąd honorowy itp.)". Wiąże się z tym paradoks tak zwanych free-riderów - osiągania korzyści przez tych, którzy jako pierwsi naruszają przyjęte zasady, lecz także strat tych, którzy do tego procederu dołączają później (szczególnie tracą ostatni). Wnioski z tego paradoksu można wyciągać różne, lecz także taki, że wprawdzie korzystne jest powszechne stosowanie kodeksów, lecz jeśli wszyscy je stosują, to nie są one potrzebne. Podobnie skuteczność kodeksów jako regulatora zachowań w organizacji widzi M. Rybak ${ }^{14}$.

Odrębnym problemem jest kwestia użyteczności kodeksów etycznych firm. B. Klimczak widzi ich użyteczność w następujących dziedzinach: informacyjnej (czego można oczekiwać od firmy, czego wymaga się od pracowników), aksjologicznej (wskazywanie wartości, rozwijanie poziomu moralnego pracowników i budowanie etosu firmy), społecznej (inspirowanie dyskusji o społecznej odpowiedzialności firm) ${ }^{15}$.

M. Rybak wskazuje na różnice w podejściu do kodeksów etycznych u firm amerykańskich i europejskich. W firmach amerykańskich kodeksy występują częściej i pojawiły się wcześniej. W badaniach z lat dziewięćdziesiątych XX wieku okazało się, że różnice dotyczą też treści podejmowanych problemów. W firmach europejskich we wszystkich kodeksach obecne są sformułowania dotyczące pracowników, podczas gdy w firmach amerykańskich zapisy takie posiada $55 \%$ kodeksów ${ }^{16}$. Autorka wskazuje także na inne różnice oraz zauważa ewolucję treści kodeksów i podejmowanie przez nie nowych problemów.

Wśród firm, a także wśród etyków biznesu, występują odmienne podejścia do określenia roli etyki w działalności gospodarczej. W szczególności zauważa się dwie podstawowe orientacje: profitową i społeczną ${ }^{17}$. Zdaniem

12 B. Klimczak, op. cit., s. 74.

${ }^{13}$ R. Banajski, Treści aksjologiczne kodeksów etycznych regulujących sferę życia gospodarczego, [w:] Etyka biznesu w działaniu. Doświadczenia i perspektywy, red. W. Gasparski, J. Dietl, Warszawa 2001.

${ }^{14}$ M. Rybak, op. cit., s. 140.

${ }^{15}$ B. Klimczak, op. cit., s. 76.

16 Ibidem, s. 141.

17 A. Lewicka-Strzałecka, Etyczne standardy firm i pracowników, Warszawa 1999, s. 39-45. 
zwolenników orientacji profitowej, celem przedsiębiorstwa jest uzyskiwanie (przy przestrzeganiu norm prawa oraz obyczajów i norm moralnych) jak największego zysku - zadaniem menadżerów jest działanie na rzecz swoich pracodawców, czyli właścicieli. Natomiast według zwolenników orientacji społecznej, zadaniem przedsiębiorstwa jest nie tylko osiąganie zysku, lecz również realizacja pewnych celów społecznych. Menadżerowie mają obowiązki nie tylko wobec właścicieli, lecz także wobec społeczeństwa.

\section{Metoda badawcza}

Przystępując do badania, sformułowaliśmy kilka pytań, na które poszukiwaliśmy odpowiedzi. Są to następujące kwestie:

- Jakie są oczekiwania twórców kodeksów wobec tych dokumentów? Czy i jakie dają odpowiedzi na pytanie: po co kodeksy?

- Jaki typ orientacji etycznej obecny jest $\mathrm{w}$ badanych dokumentach?

- Kim są twórcy/sygnatariusze kodeksów? Czy kodeksy powstają w efekcie dyskusji z interesariuszami? Kto „zarządza” etyką, a więc, w szczególności, czy w kodeksach etycznych przewidziani są rzecznicy do spraw etyki lub podobne instytucje?

- Jacy interesariusze i w jakim stopniu są obecni w kodeksach?

- Czy analizowane kodeksy są zintegrowanie, czy też posiadają jakieś wewnętrzne napięcia, niespójności podważające ich znaczenie?

- Czy istnieją zróżnicowania preferencji aksjologicznych między kodeksami firm o zasięgu międzynarodowym i krajowym?

Odwołując się do wcześniej zasygnalizowanych oczekiwań formułowanych wobec kodeksów etycznych, można przedstawić następujące odpowiedzi-hipotezy badawcze:

- Celem kodeksów jest poinformowanie interesariuszy o zobowiązaniach firmy wobec nich i przez to budowanie jej lepszego wizerunku.

- Kodeksy powinny reprezentować orientację społeczną (a nie profitową), ponieważ w przeciwnym przypadku nie ma sensu trud ich przygotowania.

- Kodeksy powinny być efektem dialogu z interesariuszami oraz przewidywać istnienie odrębnych instytucji (np. rzecznika do spraw etyki) odpowiedzialnych za ich (tj. kodeksów) wdrażanie, ocenę, przestrzeganie.

- W kodeksach, w równym (a przynajmniej porównywalnym) stopniu powinni być obecni co najmniej następujący interesariusze: właścicie- 
le, pracownicy, dostawcy, klienci, środowisko przyrodnicze, państwo, środowisko lokalne.

- Kodeksy powinny być dokumentami zintegrowanymi, bez wewnętrznych sprzeczności.

- Oczekiwania wobec firm o zasięgu międzynarodowym są większe (posiadają one „wyższe” standardy etyczne) niż wobec firm krajowych.

Analizie poddano 49 kodeksów. Pozyskane zostały one z Internetu, ze stron firm, które przyjęły i opublikowały kodeks. Punktem wyjścia dla pozyskania odpowiednich dokumentów było wpisanie do wyszukiwarki hasła „kodeksy etyczne firm”. Z naszego punktu widzenia jest to dobór przypadkowy, a przynajmniej jest to dobór o nieznanych nam regułach. $Z$ pewnym zastrzeżeniem można więc powiedzieć, że wyniki analizy mogą być charakterystyczne, znaczące dla najczęściej wybieranych w Internecie kodeksów etycznych firm.

Przeanalizowane kodeksy są sygnowane przez firmy o różnym charakterze. Są wśród nich bardzo duże przedsiębiorstwa międzynarodowe (lub ich krajowe oddziały), produkcyjne, handlowe, budowlane, usługowe, są firmy krajowe, duże i bardzo małe, lokalne, także o zróżnicowanym profilu działania. W analizowanych kodeksach etycznych 28 (57,1\%) jest sygnowanych przez firmy o zasięgu ponadnarodowym i ich polskie oddziały. Natomiast 21 (42,9\%) sygnowanych jest przez firmy o zasięgu krajowym. Do tej grupy zaliczyliśmy również kilka dużych firm - niektóre $\mathrm{z}$ nich wykraczają w swym działaniu poza Polskę, jednak są na Giełdzie Papierów Wartościowych w Warszawie. Jest ich jednak zbyt mało (cztery firmy), aby było sensowne ich wydzielenie w odrębną grupę, dlatego w analizie włączyliśmy je do firm krajowych ${ }^{18}$. Poniżej przedstawiamy najważniejsze wyniki badań.

\section{Po co kodeks?}

W części kodeksów pojawiają się (raczej mało rozbudowane) odpowiedzi na pytanie o powody ich tworzenia. Można wyodrębnić następujące wątki:

${ }^{18}$ Nie podajemy nazw konkretnych firm, których kodeksy poddaliśmy analizie (na potrzeby badań zostały one zakodowane), wskazujemy tylko podstawowe informacje o rodzaju aktywności danej firmy. Powodem była chęć uchwycenia zasadniczych postaw obecnych w kodeksach etycznych, a nie chwalenie bądź krytykowanie konkretnych kodeksów i firm. 
1. Zadaniem kodeksu jest chronić i utrwalać dobry wiz e r u n e k f i r m y, ponieważ reputacja jest ważna dla odnoszenia sukcesów, uwiarygodnia firmę. Taką argumentację można zauważyć w piętnastu kodeksach $(30,61 \%)$.

2. Kodeks odzwierciedla dążenie do doskonałości, profesjonalizmu, poprawia kulturę organizacyjną, jest spisem dobrych praktyk, jest elementem kultury korporacyjnej. Tego typu argumenty występują w czternastu kodeksach $(28,57 \%)$.

3. Kodeks określa podstawowe wartości, których wszyscy powinni przestrzegać. W zmieniającym się świecie określa jasne s tand a r y z a c how ań. Takie wątki można zauważyć w sześciu kodeksach (12,24\%).

4. Kodeks jest pomocny przy podejmowaniu właściwych decyzji, jest poradnikiem służącym podejmowaniu takich decyzji. Argumenty tego rodzaju występują w sześciu kodeksach (12,24\%).

5. Kodeks formalizuje wartości i tak realizowane, lecz dotąd przekazywane ustnie. Argumentacja tego typu występuje w pięciu kodeksach $(10,20 \%)$.

6. W krajach, gdzie funkcjonują zróżnicowane normy, kodeks etyczny buduje jednolity obraz firmy. Do takiego argumentu odwołują się trzy kodeksy $(6,12 \%)$.

7. Kodeks etyczny je s t mora lny m funda m e n te m, bez którego nie może istnieć gospodarka wolnorynkowa. Taki argument jest obecny w jednym kodeksie.

8. Kodeks etyczny służy budowaniu równowagi mię$\mathrm{dzy}$ ekonomią a etyką. Ten argument występuje także w jednym kodeksie.

\section{Typ orientacji etycznej}

Orientacja profitowa ujawnia się przede wszystkim $\mathrm{w}$ instrumentalnym traktowaniu etyki - celem jest dobro firmy, i trudno zauważyć, aby coś innego było uznane za wartość autonomiczną. Celem jest wzrost wartości firmy, uzyskanie pozycji regionalnego lidera i zapewnienie akcjonariuszom długotrwałego zysku, efektywne i ekonomiczne zarządzanie przedsiębiorstwem.

W orientacji społecznej przedstawiana jest cała paleta celów (dóbr, wartości) realizowanych przez firmę. Zysk firmy, korzyści ekonomiczne traktowane są jako bardzo ważne, ale nie jedyne zadanie. 
W zdecydowanej większości przypadków (37) autorzy kodeksów deklarują aprobatę dla wielu wartości leżących u podstaw działalności firmy, dlatego można je zaliczyć do orientacji społecznej. W ośmiu przypadkach ujawnia się ich orientacja profitowa, a w czterech przypadkach nie udało się stwierdzić, jaką orientację prezentują.

Wyraźne są różnice w typach orientacji etycznej kodeksów firm międzynarodowych i krajowych. W kodeksach firm międzynarodowych orientacja profitowa obecna jest w 7,1\% (orientacja społeczna w 85,7\% kodeksów, w części kodeksów trudno wskazać typ orientacji), natomiast w kodeksach firm krajowych - w 28,6\% (orientacja społeczna - 61,0\%, w części kodeksów trudno wskazać typ orientacji).

\section{Kim są twórcy kodeksów etycznych firm?}

Tylko w czterech kodeksach $(8,2 \%)$ znajdują się informacje, że powstały one $\mathrm{w}$ efekcie jakichś dyskusji (przede wszystkim z pracownikami): w jednym przypadku podano informację, że kodeks był dyskutowany w formie „warsztatów”, w następnym przypadku z treści kodeksu wynika, że jego przygotowanie, przyjmowanie wniosków, uwag, propozycji było i jest zadaniem Zespołu ds. Kodeksu Etycznego, w kolejnym (choć dokument jest sygnowany przez władze spółki) jest informacja, że na jego kształt wywarła wpływ kultura korporacyjna wielu oddziałów firmy, w czwartym przypadku można uznać, że deklaracja zawarta w kodeksie jest bliska warunkom dialogu partnerów społecznych.

Aż w 44 przypadkach $(89,8 \%)$ kodeksy są efektem jednostronnych (bez informacji o udziale interesariuszy) władczych decyzji władz firmy (rady nadzorczej, zarządu, ich wspólnej decyzji bądź konkretnych osób z tego grona). Podawane są nawet daty oraz numery uchwał zatwierdzających. Pojawiają się uwagi, że władze firmy (nawet udziałowcy) identyfikują się z kodeksem. W niektórych kodeksach znajduje się uwaga, że co jakiś czas kodeks podlega ocenie i aktualizacji. $W$ jednym przypadku obecna jest także informacja, że kodeks został przygotowany przez zewnętrzną instytucję. W jednym przypadku nie można jednoznacznie określić, w jakim trybie kodeks został opracowany i przyjęty.

W sprawie sposobu powstania kodeksu między firmami międzynarodowymi i krajowymi nie ma znaczących różnic. W przypadku firm międzynarodowych w 92,9\% przypadków kodeks jest rezultatem decyzji władz firmy, a w przypadku firm krajowych - w 85,7\%. Odpowiednio, w kodeksach firm krajowych nieco częściej kodeks jest efektem jakiegoś dialogu 
partnerów społecznych, ale przy tak nielicznej grupie tego typu kodeksów różnica $\mathrm{w}$ stosunku do firm międzynarodowych jest znikoma $(9,5 \% \mathrm{w}$ firmach krajowych i 7,1\% w firmach międzynarodowych).

$\mathrm{W}$ dwunastu kodeksach $(24,5 \%)$ obecny jest zapis o istnieniu $\mathrm{w}$ firmie rzecznika do spraw etyki lub podobnej instytucji, której celem jest wdrażanie zasad kodeksu. W dwudziestu kodeksach (40,8\%) zadanie przestrzegania zasad kodeksu przypisuje się kolejnym strukturom menadżerskim - działowi kadr. Oznacza to, że "zarządzanie" sprawami etyki nie jest wyodrębnione $\mathrm{z}$ innych zadań, którymi obarczeni są menadżerowie. Takie rozwiązanie jest gorsze od powołania jakiejś specjalistycznej instytucji etycznej, bo nie ma wewnętrznego zróżnicowania władz na władzę techniczno-organizacyjną i etyczną - przekazując menadżerom nadzór etyczny, przyjmuje się, że inni interesariusze nie mają wystarczających kompetencji, aby rozstrzygać dylematy etyczne. Rzecznicy do spraw etyki częściej występują w kodeksach firm międzynarodowych (8 na 12 kodeksów przewiduje istnienie rzeczników do spraw etyki) niż w krajowych. Tam także częściej występuje sytuacja, w której menadżerowie firmy odpowiedzialni są za pieczę nad przestrzeganiem kodeksu (w 15 kodeksach na 20).

\section{Stosunek do interesariuszy}

W analizowanych kodeksach etycznych firm występują następujące preferencje dotyczące interesariuszy. W każdym kodeksie znajdują się zapisy dotyczące pracowników. Następni są klienci oraz państwo. Obie grupy obecne są w 44 kodeksach (tj. w 89,8\%). W dalszej kolejności występują zapisy dotyczące środowiska przyrodniczego (w 75,5\% kodeksów), dostawców i społeczności lokalnych (w 73,5\% kodeksów) i na końcu listy wyborów znajdują się właściciele (w 55,1\% kodeksów) ${ }^{19}$.

\section{Problem integralności deklaracji kodeksów etycznych firm}

W części analizowanych kodeksów etycznych firm pojawiają się wyraźne sprzeczności między deklarowanymi zapisami. Zasygnalizujemy dwa przykłady, choć jest ich znacznie więcej i dotyczą przede wszystkim relacji między prawami i obowiązkami pracowniczymi.

19 Dokładne omówienie stosunku do interesariuszy znajdują się w książce T. Czakona: Między paternalizmem a restrykcyjnościq..., op. cit. 
W sześciu analizowanych dokumentach $(12,2 \%)$ istnieją deklaracje, że kodeks nie jest zobowiązaniem firmy bądź nie tworzy on podstaw do roszczeń umownych. Taka formuła występuje w 14,3\% kodeksów firm o zasięgu międzynarodowym i w 9,5\% kodeksów firm krajowych. Należy wobec tego zapytać, po co firmy go opracowały i informują o jego istnieniu?

W pięciu kodeksach (w 10\% ogółu) występują jednocześnie deklaracje, że jego przestrzeganie jest obowiązkiem pracowników zagrożonym karami dyscyplinarnymi, włącznie ze zwolnieniem z pracy. To znaczy, że z jednej strony kodeksy te deklarują, iż ich zapisy nie są zobowiązaniem firmy, $\mathrm{z}$ drugiej nakładają na pracowników obowiązek ich przestrzegania.

Drugi przykład dotyczy z jednej strony deklarowania, że pracownicy firmy powinni być profesjonalistami, a z drugiej - braku informacji o ułatwianiu im osiągnięcia takiej pozycji. W osiemnastu kodeksach $(36,7 \%)$ twórcy domagają się od pracowników perfekcjonizmu i profesjonalizmu, lecz tylko $\mathrm{w}$ dwunastu $\mathrm{z}$ nich są zapisy wskazujące na potrzebę pomagania pracownikom $\mathrm{w}$ uzyskiwaniu umiejętności w postaci szkoleń. Oznacza to, że w sześciu (12,2\% ogółu), tj. 1/3 kodeksów domagających się perfekcjonizmu i profesjonalizmu nie zauważa się potrzeby pomagania pracownikom w uzyskaniu takich umiejętności.

\section{Wnioski. Dominujące wyobrażenia dobra}

W kodeksach etycznych firm nie znajdziemy szczegółowych rozważań dotyczących tego, czym jest dobro, choć analiza ich treści ukazuje, co uznają za dobro ich twórcy. Wyobrażenia te zawarte są w preferowaniu pewnych regul, wartości i pomijaniu lub zapominaniu o innych. Analiza 49 kodeksów doprowadziła do odpowiedzi na postawione hipotezy badawcze dotyczące przypuszczalnych preferencji wyboru wartości (dobra).

Hipoteza pierwsza: celem kodeksów jest poinformowanie interesariuszy o zobowiązaniach firmy wobec nich i przez to budowanie jej lepszego wizerunku.

W analizowanych dokumentach sprawa nie jest tak jednoznaczna. Można tylko stwierdzić, że zgodnie z deklaracjami twórców, kodeksy służą budowaniu lepszego wizerunku, lecz jednocześnie w znaczącej części kodeksów obecne są zapisy, że kodeksy nie są zobowiązaniami firm, co podważa wiarygodność złożonych deklaracji i tym samym nie kształtuje dobrego wizerunku. Taka sytuacja może być uznawana za przejaw niekonsekwencji, 
asekuracji, instrumentalnego traktowania etyki w postaci kodeksu, a być może po prostu niekompetencji ich twórców.

Hipoteza druga: kodeksy powinny reprezentować orientację społeczną, a nie profitową.

Ta hipoteza została w pewnej mierze potwierdzona - większość kodeksów (61\% krajowych i 85,7\% międzynarodowych) zawiera deklaracje pozwalające na taką kwalifikację firmy. Jednak wśród analizowanych kodeksów istnieje liczna grupa dokumentów (16,3\% ogółem, w tym 7,1\% firmy międzynarodowe, $28,6 \%$ firmy krajowe) reprezentujących orientację profitową. Przewaga kodeksów deklarujących orientację społeczną może być związana z poprawnością polityczną - modną i nośną stała się idea społecznej odpowiedzialności biznesu, każda firma dbająca o społeczny odbiór musi w jakiejś mierze starać się o taki wizerunek. Kodeksy, w których deklaruje się orientację społeczną, zwykle zawierają pewien zespół wartości-dóbr, które uznaje się za szczególnie ważne.

Hipoteza trzecia: kodeksy powinny być efektem dialogu z interesariuszami i powinny przewidywać istnienie odrębnych instytucji (np. rzecznika do spraw etyki) odpowiedzialnych za jego wdrażanie, ocenę, przestrzeganie.

Preferencje kodeksów są odmienne (przeciwstawne) od wyobrażeń etyków. Tylko w nielicznych $(8,2 \%)$ kodeksach obecne są informacje o jakichkolwiek elementach dialogu z interesariuszami. Znacznie częściej $(24,5 \%)$ w kodeksach przewidziane jest istnienie odrębnych, "etycznych" instytucji. Najczęściej kodeks powstaje w sposób odgórny, nie partnerski, a jego twórcy zakładają, że sami potrafią nieomylnie wskazać pożądany standard działalności biznesowej, tym samym przypisując sobie przewagę epistemologiczną także w zakresie obyczaju, moralności (uważają, że lepiej wiedzą, co jest dobre dla interesariuszy - szczególnie pracowników). Kodeksów partnerskich (zakładających podmiotowość pracowników) nie ma, przeważają autorytarne, restrykcyjne, paternalistyczne lub łączące ze sobą te trzy cechy ${ }^{20}$.

Hipoteza czwarta: w kodeksach powinni występować wszyscy interesariusze $\mathrm{w}$ porównywalnym stopniu.

Wbrew przypuszczeniom, różne grupy interesariuszy występują w kodeksach w bardzo zróżnicowanej częstotliwości. We wszystkich obecne są zapisy dotyczące pracowników, co jednak nie oznacza, że pracownicy trak-

${ }^{20}$ Zob. T. Czakon, op. cit., s. 173 i n. 
towani są jak partnerzy. Najrzadziej występują zapisy dotyczące właścicieli, co z kolei nie oznacza, że faktycznie są oni dyskryminowani. Tak więc sama częstotliwość zapisów dotyczących poszczególnych grup (pracownicy, właściciele) nie odzwierciedla w pełni stosunku do ich interesów, dóbr chronionych. Dopiero analiza treści tych zapisów pozwala orzec, czyje i jakie interesy są uznawane za priorytetowe i chronione.

Hipoteza piąta: Kodeksy powinna cechować integralność (brak sprzeczności, niekonsekwencji).

Hipoteza ta nie potwierdziła się. W kodeksach występują liczne konfliktowe zapisy, co jest poważną wadą świadczącą między innymi o jakimś braku w spójności myślenia lub rozdźwięku między deklaracjami a motywacją. Do najbardziej jaskrawych niekonsekwencji zaliczyliśmy wyznaczanie misji, wizji, fundamentalnych wartości i powinności z jednoczesnym zastrzeżeniem, że kodeks nie jest zobowiązaniem firmy.

Hipoteza szósta: kodeksy firm międzynarodowych zawierają wyższe standardy etyczne niż kodeksy firm krajowych.

Analiza tego nie potwierdziła. Obie grupy firm posiadają kodeksy o porównywalnych standardach, przy czym $w$ niektórych kwestiach jedna grupa firm charakteryzuje się wyższymi standardami, a w innych - druga.

Twórcy kodeksów mają ogólne wyobrażenie dobra, odnoszą je głównie do sfery działalności biznesowej i sprawnego zarządzania firmą. Dobro ma dla twórców kodeksów przede wszystkim wymiar ekonomiczny - to interes, korzyść, zysk. Dzieje się tak także w tych kodeksach, które deklarują wierność zasadom społecznej odpowiedzialności biznesu. Jeśli pojawia się odniesienie do dobra moralnego (godność człowieka, prawa człowieka do rozwoju, jakości życia, prywatności), to jest ono podporządkowane dobru $\mathrm{w}$ znaczeniu pragmatycznym, instrumentalnym. I $\mathrm{z}$ tego powodu wiele $\mathrm{z}$ analizowanych kodeksów nie zasługuje na nazwę „kodeks etyczny”. Oczekiwania etyków wobec sposobu tworzenia, treści i funkcji kodeksów etycznych są spełniane $\mathrm{w}$ nikłym stopniu. Sfera powinności, wyznaczana przez etyków, a sfera faktyczności (kształt i sposób tworzenia kodeksów) są od siebie tak odległe, że pojawia się uzasadniony sceptycyzm wobec sensowności etyki biznesu - cóż znaczą jej ustalenia, postulaty, skoro nie są stosowane, nawet w sferze deklaracji? Analiza kodeksów ujawnia jeszcze jedno - światową tendencję do ograniczania, nierespektowania, w końcu pozbawiania praw pracowniczych. Ta grupa jest w najgorszej sytuacji - wbrew występu- 
jącym czasem zapewnieniom, że pracownicy stanowią podstawę działalności i rozwoju firmy, w rzeczywistości są traktowani w sposób niepodmiotowy i nieautonomiczny. Pod hasłem troski o dobro firmy, dostosowania do zmiennej sytuacji na rynku, dobra pracowników (pojmowanego jako możliwość jakiejkolwiek pracy) nakłada się na nich coraz więcej obowiązków, o prawach nie ma mowy lub są to tylko puste deklaracje. Na te tendencje współczesnego, elastycznego kapitalizmu zwracają uwagę niektórzy ekonomiści, socjologowie, filozofowie (J. Rifkin, R. Sennett, C. Offe, Z. Bauman) ${ }^{21}$, czasem znajdziemy też niepokojące doniesienia prasowe mówiące o rosnącej tendencji zawierania „śmieciowych" umów o pracę22. Kodeksy są zbiorem deklaracji, postulatów, ale i w tej sferze znajduje odbicie rzeczywistość, w której współcześnie żyjemy, i postawy ludzi, którzy takie dokumenty stanowią.

\section{What is Defined as Good in Company Codes of Ethics?}

\section{Summary}

The paper concentrates on the problem of company codes of ethics. We want to present how the authors define what is desirable for company and stakeholders. From our point of view, company codes of ethics contain different axiological preferences. Our aim is to focus on these aspects of codes which are related with problems such as: way of creation code of ethics, perceived role of code of ethics, attitude towards main stakeholders. Our analysis will show how companies defines what is good in their activity (and what is good in general). Evaluation their ethicality will be based on comparison of contents company codes of ethics (demands, liabilities) with requirements of the business ethicists.

${ }^{21}$ Por. J. Rifkin, Koniec pracy. Schyłek sity roboczej na świecie i początek ery postrynkowej, tłum. E. Kania, Wrocław 2001; R. Sennett, Korozja charakteru. Osobiste konsekwencje pracy w nowym kapitalizmie, tłum. J. Dzierzgowski, Ł. Mikołajewski, Warszawa 2006; idem, Kultura nowego kapitalizmu, tłum. G. Brzozowski, K. Osłowski, Warszawa 2010; Z. Bauman, Praca, konsumpcjonizm i nowi ubodzy, tłum. S. Obirek, Kraków 2006. Omówienie zasadniczych tez wymienionych autorów znajduje się w: D. Ślęczek-Czakon, Praca i zbyteczność we wspótczesnym świecie, [w:] Praca i bezrobocie jako determinanty bezpieczeństwa narodowego, red. M. Kasperski i T. Szczurek, Warszawa 2010, s. 271-279.

22 Por. M. Czarnecki, Wyzerowani pracownicy. "Gazeta Wyborcza” z 7 sierpnia 2013, s. 12. W artykule podano, że tylko w Wielkiej Brytanii milion pracowników ma „elastyczne” umowy o pracę - są to umowy na " 0 " godzin, pracodawca nie gwarantuje pracy, wzywa pracownika, gdy go potrzebuje, płaci tylko za wykonane godziny. Większość ludzi, w sytuacji rosnącego bezrobocia, braku stabilnego zatrudnienia, zmuszona jest takie umowy podpisać. 